Volume 7 Nomor 2 Tahun 2019

\title{
Penggunaan Model Inkuiri Terbimbing dengan Media Kertas Lipat dalam Peningkatan Pembelajaran Matematika tentang Penjumlahan dan Pengurangan Pecahan pada Siswa Kelas V SDN Roworejo Tahun Ajaran 2017/2018
}

\author{
1,2,3Universitas Sebelas Maret \\ aniqotulkhusnaa@gmail.com
}

Aniqotul Khusna ${ }^{1}$, Imam Suyanto ${ }^{2}$, Joharman ${ }^{3}$

\section{Article History}

accepted 01/06/2019

approved 01/07/2019

published 01/08/2019

\begin{abstract}
The objective of this research is to improve mathematic education about addition and subtraction on fraction through the application of guided inquiry model using folding paper media. This research is a collaborative Classroom Action Research (CAR). Subjects of the research were 22 students the Fifth Grade Students of SD Negeri Roworejo. The research conducted of three cycles. Each cycle consisted of planning, action, observation, and reflection. The conclusion of this research is the use of guided inquiry model using folding paper media can improve mathematic education about addition and subtraction on fraction.
\end{abstract}

Keywords: Guided Inquiry, Folding Paper, Mathematic

\begin{abstract}
Abstrak
Tujuan penelitian ini adalah meningkatkan pembelajaran matematika tentang penjumlahan dan pengurangan pecahan melalui penerapan model inkuiri terbimbing dengan media kertas lipat. Penelitian ini merupakan penelitian tindakan kelas secara kolaboratif. Subjek penelitian ini adalah 22 siswa kelas V SDN Roworejo. Penelitian terdiri dari 3 siklus. Setiap siklus terdiri dari perencanaan, pelaksanaan, pengamata dan refleksi. Hasil penelitian ini menujukkan bahwa penerapan model inkuiri terbimbing dengan media kertas lipat dapat meningkatkan pembelajaran matematika tentang penjumlahan dan pengurangan pecahan.
\end{abstract}

Kata kunci: Inkuiri terbimbing, Kertas lipat, Matematika 


\section{PENDAHULUAN}

Pendidikan merupakan hal penting dan utama bagi setiap bangsa dan negara untuk menciptakan sumber daya manusia yang berkualitas dan bermutu. pendidikan tidak semata-mata mementingkan intelektualitas saja, akan tetapi lebih ditekankan pada proses pembinaan kepribadian anak didik secara menyeluruh sehingga anak menjadi lebih dewasa. Pembelajaran sebagai proses pendidikan yang berlangsung di sekolah dasar merupakan upaya mengembangkan sikap, kecerdasan, serta keterampilan peserta didik. Pembelajaran akan lebih bermakna dan mudah dipahami siswa apabila siswa dapat terlibat secara langsung dalam pembelajaran. Teori ausubel menyatakan bahwa kebermaknaan pembelajaran akan membuat kegiatan belajar lebih menarik, lebih bermanfaat dan lebih menantang sehingga konsep yang diajarkan dapat lebih mudah dipelajari dan mempunyai masa ingatan yang lebih lama bagi peserta didik (Muhsetyo, 2014: 1.9). matematika merupakan ilmu deduktif yang abstrak, sehingga dalam pembelajarannya harus merupakan belajar bermakna agar dapat lebih dipahami oleh siswa.

Berdasarkan hasil wawancara dan observasi proses pembelajaran matematika yang telah dilaksanakan peneliti pada hari Selasa, 7 November 2017, diperoleh informasi bahwa kegiatan pembelajaran belum menimbulkan interaksi dua arah antara guru dengan siswa serta kurang bermakna bagi siswa, sehingga menyebabkkan siswa kurang terlibat secara aktif dan kurang antusisas dalam pembelajaran. Guru belum menggunakan media yang dapat dimanipulatif untuk dapat menunjang proses pembelajaran matematika. Hal teresbut berdampak pada rendahnya aktifitas siswa dalam pembelajaran matematika yang dibuktikan dengan rendahnya hasil belajar matematika siswa kelas V SDN Roworejo pada UTS I tahun ajaran 2017/2018 yaitu terdapat $41 \%$ dari 22 siswa yang mendapat nilai dibawah KKM 75.

Berdasarkan permasalahan tersebut, perlu diadakan perbaikan agar dapat meningkatkan pembelajaran khususnya pada pembelajaran matematika. guru perlu memilih suatu strategi pembelajaran yang efektif yaitu dengan menerapkan model pembelajaran dengan memanfaatkan media pembelajaran konkret untuk meningkatkan pemahaman siswa mengenai konsep-konsep materi yang bersifat abstrak.

Siswa kelas V SD rata-rata berusia sekitar 10-12 tahun, sehingga digolongkan ke dalam tahap operasional konkret. Buhler menjelaskan bahwa anak usia 9-11 tahun merupakan masa mencoba, menyelidik dan bereksperimen, yang distimulusi oleh dorongan-dorongan menyelidik dan rasa ingin tahu yang besar, masa pemusatan dan penimbunan tenaga untuk berlatih, menjelajah dan bereksplorasi (Sobur, 2003:132). Mereka mampu mengoordinasikan pemikiran suatu ide ke dalam pemikirannya sendiri dan mampu berpikir secara logis dan sistematis tentang objek-objek yang bersifat konkret yang mereka temukan melalui pengalaman langsung.

Pembelajaran matematika merupakan suatu kegiatan yang dirancang oleh guru secara sistematis yang melibatkan komunikasi dua arah antara guru dan peserta didik serta sumber belajar, mengenai penelaahan bentuk-bentuk atau struktur objek yang abstrak berupa definisi-definisi, aksioma-aksioma, dan dalil-dalil yang telah dibuktikan kebenarannya serta hubungan antara objek tersebut yang dibangun melalui proses penalaran deduktif untuk mengembangkan dan memperoleh pengalaman belajar serta pengetahuan baru bagi peserta didik.

Inkuiri merupakan salah satu pembelajaran berbasis penemuan. Muhsyeto, dkk. (2014: 1.35) menjelaskan bahwa inkuiri terbimbing adalah suatu kegiatan pembelajaran yang mana guru membimbing siswa-siswanya dengan menggunakan langkah-langkah yang sistematis sehingga mereka merasa menemukan sesuatu. 
siswa dibimbng untuk menemukan konsep dan informasi secara mandiri serta dapat memecahkan masalah melalui pertanyaan, memeriksa dan penyelidikan.

Menurut Nuryani (2013: 3), media kertas lipat adalah media yang terbuat dari kertas yang berwarna dan bisa digunakan untuk melipat-lipat menjadi lipatan bagian yang sama besar.

Penerapan model inkuiri terbimbing dengan media kertas lipat merupakan pola pembelajaran yang melibatkan kemampuan siswa untuk menemukan konsep, informasi dan pemecahan masalah secara mandiri melalui pertanyaan, memeriksa dan penyelidikan dengan menggunakan media yang terbuat dari kertas tipis yang dapat dilipat menjadi bagian yang sama besar yang disertai bimbingan intensif dari guru. Adanya penerapan model inkuiri terbimbing dengan media kertas lipat ini diharapkan dapat membuat pembelajaran lebih menarik, menyenangkan dan dapat bermakna bagi siswa sehingga dapat memudahkan siswa dalam memahami materi serta memiliki daya ingat yang lebih lama. Siswa aktif dalam pembelajaran untuk menuangka ide-ide, skill yang dimilikinya. Dengan demikian, pembelajaran matematika dapat meningkat.

Rumusan masalah dari penelitian tindakan kelas ini yaitu: (1) bagaimana langkah-langkah penerapan model inkuiri terbimbing dengan media kertas lipat dalam peningkatan pembelajaran matematika tentang penjumlahan dan pengurangan pecahan; (2) apakah penerapan model inkuiri terbimbing dengan media kertas lipat dapat meningkatkan pembelajaran matematika tentang penjumlahan dan pengurangan pecahan? Sedangkan tujuan penelitian ini yaitu: (1) mendeskripsikan langkah-langkah penerapan model inkuiri terbimbing dengan media kertas lipat dalam peningkatan pembelajaran matematika tentang penjumlahan dan pengurangan pecahan; (2) meningkatkan pembelajaran matematika tentang penjumlahan dan pengurangan pecahan melalui penerapan model inkuiri terbimbing dengan media kertas lipat.

\section{METODE}

Penelitian ini merupakan penelitian tindakan kelas kolaboratif yaitu peneliti bekerjasama dengan guru dalam melaksanakan penelitian. Penelitian ini dilaksanakan di SDN Rororejo. Subjek penelitian ini adalah siswa kelas $V$ yang berjumlah 22 siswa.

Teknik pengumpulan data dalam penelitian ini menggunakan teknik tes dan nontes. Instrument penelitian berupa lembar observasi terhadap guru dan siswa, pedoman wawancara, lembar evaluasi. Data yang digunakan berupa data kuantitatif dan data kualitatif. Mengacu pada pendapat Miles dan Huberman yang menjelaskan bahwa terdapat 3 tahapan dalam analisis data dimulai dari reduksi data, penyajian data, dan penarikan kesimpulan (Sugiyono, 2012: 246-253). Validitas data dalam penelitian ini menggunakan triangulasi sumber, triangulasi teknik dan validitas isi. Triangulasi sumber data yang digunakan pada penelitian ini yaitu siswa, guru, dan dokumen. Triangulasi teknik yang digunakan berupa teknik tes, observasi, dan wawancara. Sedangkan validitas isi dalam penelitian ini dilakukan dengan mencocokkan materi tes dengan silabus dan kisi-kisi, melakukan diskusi dengan pendidik, dan mencermati kembali substansi dan konsep yang akan diukur. Indikator kinerja peningkatan pembelajaran matematika tentang penjumlahan dan pengurangan pecahan yaitu mencapai $\geq 85 \%$ meliputi penerapan langkah model inkuiri terbimbing dengan media kertas lipat dan mencapai $\geq 80 \%$ untuk hasil belajar siswa.

Penelitian ini dilaksanakan dalam 3 siklus. Pada siklus I dan siklus II terdiri dari 2 pertemuan sedangkan pada siklus III hanya dilaksanakan 1 pertemuan. Arikunto (2013: 137) menjelaskan bahwa tahapan penelitian tindakan kelas meliputi planning (perencanaan), acting (tindakan/pelaksanaan), observing (observasi/pengamatan) dan reflecting (refleksi).

Pada tahap perencanaan penerapan model inkuiri terbimbing dengan media kertas lipat peneliti melakukan izin kepada SD, menyusun skenario pembelajaran dan RPP, menyiapkan media dan sumber belajar yang akan digunakan, menyiapkan 
lembar kerja siswa, lembar tes/evaluasi, lembar observasi guru dan siswa, pedoman wawancara guru dan siswa, menghubungi observer, serta melakukan koordinasi dengan guru kelas V SD Negeri Roworejo mengenai waktu pelaksanaan tindakan kelas siklus I.

Pada tahap pelaksanaan, gru melaksanakan kegiatan pembelajaran sesuai dengan skenario pembelajaran yang telah direncanakan sebelumnya. Pada tahap pengamatan peneliti dan observer mengamati saat kegiatan pembelajaran matematika yang menerapkan model inkuiri terbimbing dengan media kertas lipat terhadap guru dan siswa. Pada tahap refleksi peneliti bersama guru melakukan refleksi dan berdiskusi untuk mengkaji apakah penerapan model inkuiri terbimbing dengan media kertas lipat sesuai dengan langkah-langkah yang benar serta mencari solusi dari kendala-kendala yang dihadapi guru selama proses pembelajaran.

\section{HASIL DAN PEMBAHASAN}

Penelitian dilaksanakan dalam tiga siklus dengan 5 kali pertemuan. Pelaksanaan pembelajaran dengan menerapkan model inkuiri terbimbing dengan media kertas lipat telah dilaksanakan sesuai dengan scenario pembelajaran yang telah dibuat. Langkah penerapan model inkuiri terbimbing dengan media kertas lipat terdiri dari 7 langkah yaitu: 1) orientasi menggunakan kertas lipat, 2) perumusan masalah, 3) menyusun hipotesis, 4) mengumpulkan data dengan mengaplikasikan kertas lipat, 5) menguji hipotesis, 6) merumuskan kesimpulan, 7) mengomunikasikan hasil.

Penerapan model inkuiri terbimbing dengan media kertas lipat yang telah dilakukan dapat meningkatkan pembelajaran matematika, keberhasilan tersebut dapat dilihat dari peningkatan presentase hasil observasi terhadap guru dan siswa tentang penerapan model inkuiri terbimbing dengan media kertas lipat yang telah mencapai indicator kinerja penelitian yang telah ditentukan serta ketuntasan hasil belajar siswa. Peningkatan langkah penerapan model inkuiri terbimbing dengan media kertas lipat dapat dilihat pada tabel 1 berikut.

Tabel 1. Analisis Hasil Observasi Terhadap Guru dan Siswa dalam Penerapan Model Inkuiri Terbimbing dengan Media Kertas Lipat

\begin{tabular}{lll}
\hline Siklus & $\begin{array}{l}\text { Persentase } \\
\text { bagi guru }\end{array}$ & $\begin{array}{l}\text { Persentase } \\
\text { bagi siswa }\end{array}$ \\
\hline I & $73,02 \%$ & $70,24 \%$ \\
II & $85,52 \%$ & $85,12 \%$ \\
III & $90,08 \%$ & $89,68 \%$
\end{tabular}

Berdasarkan tabel 1 disumpulkan bahwa hasil penerapan model inkuiri terbimbing dengan media kertas lipat terhadap guru dan siswa mengalami peningkatan dari siklus I sampai siklus III. Rata-rata hasil observasi terhadap guru pada siklus I sebesar $73,02 \%$, pada siklus II mengalami peningkatan menjadi $85,52 \%$ dan pada siklus III juga mengalami peningkatan $90,08 \%$. Sedangkan rata-rata hasil observasi terhadap respon siswa pada siklus I sebesar $70,24 \%$, pada siklus II mengalami peningkatan menjadi $85,12 \%$ dan pada siklus III juga mengalami peningkatan menjadi $89,68 \%$.

Selain hasil observasi penerapan model inkuiri terbimbing dengan media kertas lipat, penelitian ini juga mengambil data nilai hasil belajar siswa tentang penjumlahan dan pengurangan pecahan melalui penerapan model inkuiri terbimbing dengan media kertas lipat. Perbandingan nilai hasil belajar siswa pada siklus I, siklus II dan siklus III dapat dilihat pada tabel 2 berikut.

Tabel 2. Perbandingan Nilai Hasil Belajar Siklus I, Siklus II dan Siklus III 


\begin{tabular}{lccc}
\hline Hasil & Siklus & \multicolumn{2}{l}{ Siklus } \\
Belajar & I & II & III \\
\hline Rata-rata & 76,85 & 84,48 & 91,40 \\
$\begin{array}{l}\text { Persentase } \\
\text { tuntas }\end{array}$ & $69,91 \%$ & $83,64 \%$ & $90,91 \%$ \\
$\begin{array}{l}\text { Persentase } \\
\text { belum tuntas }\end{array}$ & $30,09 \%$ & $16,36 \%$ & $9,09 \%$ \\
\hline
\end{tabular}

Berdasarkan tabel 2 disimpulkan bahwa terjadi peningkatan hasil belajar siswa pada pelajaran matematika tentang penjumlahan dan pengurangan pecahan melalui penerapan model inkuiri terbimbing dengan media kertas lipat dari siklus I, siklus II dan siklus III. nilai rata-rata siswa pada siklus I adalah 76,85, pada siklus II adalah 84,48 dan pada siklus III meningkat menjadi menjadi 91,40. persentase ketuntasan pada siklus I sebesar $69,91 \%$ sedangkan persentase siswa yang belum tuntas sebesar $30,09 \%$, pada siklus II persentase siswa tuntas sebesar $83,64 \%$ dan persentase siswa belum tuntas sebesar $16,36 \%$ dan pada siklus III persentase ketuntasan sebesar $90,91 \%$, sedangkan siswa belum tuntas sebesar $9,09 \%$.

\section{SIMPULAN}

Berdasarkan hasil penelitian dapat disimpulkan bahwa penerapan model inkuiri terbimbing dengan media kertas lipat dalam peningkatan pembelajaran matematika tentang penjumlahan dan pengurangan pecahan pada siswa kelas V SDN Roworejo tahun ajaran 2017/2018 dilaksanakan dengan langkah-langkah yaitu: 1) orientasi menggunakan kertas lipat, 2) perumusan masalah, 3) menyusun hipotesis, 4) mengumpulkan data dengan mengaplikasikan kertas lipat, 5) menguji hipotesis, 6) merumuskan kesimpulan, 7) mengomunikasikan hasil. Penerapan model inkuiri terbimbing dengan media kertas lipat dapat meningkatkan pembelajaran matematika tentang penjumlahan dan pengurangan pecahan pada siswa kelas V SDN Roworejo tahun ajaran 2017/2018.

\section{DAFTAR PUSTAKA}

Arikunto, S. (2013). Prosedur Penelitian, Suatu Pendekatan Praktik. Jakarta: Rineka Cipta.

Muhsyeto, G, dkk. (2014). Pembelajaran Matematika SD edisi 1. Tangerang Selatan: Universitas Terbuka.

Nuryani, S. (2013). Meningkatkan Hasil Belajar Materi Pecahan Sederhana Menggunakan Media Kertas Lipat pada Siswa Kelas III SDN Nginden Jangkungan I / 247 Surabaya. E-journal Unesa, 4 (1), 3-4.

Sobur, A. (2003). Psikologi Umum dalam Lintasan Sejarah. Bandung: Pustaka Setia.

Sugiyono. (2012). Metode Penelitian Kuantitatif Kualitatif dan $R$ \& $D$. Bandung: Alfabeta. 